\title{
PENGEMBANGAN STRATEGI PEMBELAJARAN DAN PEIMILIHAN BAHAN AJAR
}

\author{
Muhamad Zain
}

Dosen Intitut Agama Islam Negeri Ternate

\begin{abstract}
To create a superior learning process / quality, it is necessary to develop a special strategy that makes students motivated to learn and always feel the pleasure in learning. In developing such learning strategies, students become the center of attention. criteria that must be met in the learning model or the development of learning are: 1) have a purpose; 2) harmony with purpose; 3) systematic; 4) having evaluation activities; and 5) fun. Therefore, the learning system can be likened to a production process consisting of an input-process-output part, which is mutually integrated. All professionals must have professional skills in their fields, among others, to make designs about things to do. So the problem is that the work works well. Ability to develop techniques in learning because all teachers want the results of education work well. Moreover, he is not dealing with inanimate objects, but a growing human child and developing.
\end{abstract}

Keywords: Development, Strategy, Learning and Teaching Materials

\section{PENDAHULUAN}

eberhasilan belajar seorang peserta didik dipengaruhi oleh banyak faktor, baik
faktor internal maupun eksternal. Faktor internal misalnya motivasi belajar
dari peserta didik itu sendiri. Sedangkan faktor eksternal misalnya lingkungan dan juga kemampuan professional guru. Untuk mencapai pembelajaran yang berkualitas/unggul, maka perlu dirancang strategi yang inovatif. Pembelajaran Unggul adalah proses belajar mengajar yang kembangkan dalam rangka membelajarkan semua siswa berdasarkan tingkat keunggulannya untuk menjadikannya beriman dan bertaqwa kepada Tuhan Yang Maha Esa, menguasi ilmu pengetahuan dan teknologi secara mandiri namun dalam kebersamaan, mampu menghasilkan karya yang terbaik dalam menghadapi persaigan pasar bebas.

Merujuk pada konsepsi di atas, perlu ditegaskan bahwa pembelajaran unggulan bukanah pembelajaran yang secara khusus dirancang dan dikembangkan hanya untuk siswa yang unggul darisisi akademik semata, melainkan lebih merupakan pembelajaran yang secara metodologis maupun psikologis dapat membuat semua siswa mengalami belajar secara maksimal dengan memperhatikan kapasitasnya masing-masing.

Menurut Bafadhal ada tiga indikator pembelajaran unggulan. Pertama, pembelajaran unggulan apabila dapat melayani semua siswa (bukan hanya pada sebagian siswa). Kedua, dalam pembelajaran unggulan semua anak mendapatkankan 
pengalaman belajar semaksimal mungkin. Ketiga, walaupun semua siswa mendapatkan pengalaman belajar maksimal, prosesnya sangat bervariasi bergantung pada tingkat kemampuan anak yang bersangkutan. Dengan demikian, pembelajaran yang unggul berpusat pada siswa (student center).

\section{Strategi Pembelajaran}

\section{A. Pengertian Strategi Pembelajaran}

Pendapat para ahli tentang strategi pembelajaran:

Kozma dan Gofur, bahwa strategi pembelajaran dapat diartikan sebagai setiap kegiatan yang dipilih yaitu yang dapat memberikan fasilitas atau bantuan kepada peserta didik menuju tercapainya tujuan pembelajaran tertentu.

Gerlach dan Ely, bahwa strategi pembelajaran merupakan cara-cara yang dipilih untuk menyampaikan materi pembelajaran dalam lingkungan pembelajaran tertentu. Yang meliputi sifat, lingkup, urutan kegiatan pembelajaran yang dapat memberikan pengalaman belajar kepada peserta didik.

Dick Carey, bahwa strategi pembelajaran terdiri atas seluruh komponen materi pembelajaran dan prosedur atau tahapan kegiatan yang digunakan oleh guru dalam rangka membantu peserta didik mencapai tujuan pembelajaran tertentu.

Gropper, bahwa strategi pembelajaran merupakan pemilihan atas berbagai jenis latihan tertentu yang sesuai dengan tujuan pembelajaran yang ingin di capai.

Secara teoretik strategi pembelajaran terdiri dari:

1. Expository learning X Discovery learning, pengembangan pembelajaran yang dilakukan dengan mengekspos pengetahuan-pengetahuan jadi kepada peserta didik $\mathrm{X}$ kebalikannya discovery learning adalah pengembangan pembelajaran kebalikan dari model ekspository learning, siswa disuruh mencari sendiri sumber-sumber belajar, berdasarkan panduan belajar (learning guide) yang dikembangkan guru.

2. Individual learning X Group learning;

3. Root learning X Meaningfull learning.

Strategi Pembelajaran yang dipilih oleh seorang guru hendaknya didasari berbagai pertimbangan sesuai dengan situasi, kondisi dan lingkungan yang dihadapinya. Pemilihan strategi pembelajaran umumnya bertolak dari

a. Rumusan tujuan pembelajaran yang telah ditetapkan

b. Analisis kebutuhan dan karakteristik peserta didik yang dihasilkan

c. Jenis materi pembelajaran yang dikomunikasikan.

Menurut Sanjaya ada beberapa strategi pembelajaran yang harus dilakukan oleh seorang guru:

a. Strategi pembelajaran ekspositori

b. Strategi pembelajaran inquiry

c. Strategi pembelajaran berbasis masalah

d. Strategi pembelajaran peningkatan kemampuan berpikir. 


\section{B. Mengembangkan Strategi Pembelajaran}

Pembelajaran adalah setiap perubahan perilaku yang relatif permanen, terjadi sebagai hasil dari pengalaman.Definisi sebelumnya menyatakan bahwa seorang manusia dapat melihat perubahan terjadi tetapi tidak pembelajaran itu sendiri.Konsep tersebut adalah teoretis, dan dengan demikian tidak secara langsung dapat diamati.

Berdasarkan pada pengertian pembelajaran, maka diperlukan sekurang-kurangnya lima kriteria yang harus dipenuhi dalam model pembelajaran atau pengembangan pembelajaran yaitu: 1) mempunyai tujuan; 2) keserasian dengan tujuan; 3) sistematik; 4) mempunyai kegiatan evaluasi; dan 5) menyenangkan. Oleh karena itu, sistem pembelajaran dapat diibaratkan sebagai proses produksi yang terdiri dari bagian inputproses-output, yang saling terintegrasi.

Model dick and carey digolongkan sebagai model yang berorientasi pada dua hal, yaitu:

a. Pengetahuan, apabila model tersebut dipakai sebagai sumber informasi tentang konsep-konsep, prinsip-prinsip perencenaan instruksional dan langkah -langkahya.

b. Hasil, dengan menerapkan konsep-konsep dan prinsip-prinsip perancangan yang menghasilkan suatu bahan instruksional yang dapat dipakai belajar secara mandiritanpa bantuan guru. Disini pun evaluasi dilaksanakan berulangkali sampai dapat diperoleh hasil yang memuaskan.

Seperti model-model pengembangan lainnya, disinipun dick dan carey menerapkan pendekatan sistem untuk perancang sistem instruksional dengan langkah langkah:

1. Penentuan tujuan instruksional (tujuan terminal) yang menyatakan apa yang dapat dilakukan oleh siswa setelah mengikuti program instruksional tersebut. Penentuan tujuan ini dapat bersumber dari penilaian kebutuhan tujuan-tujuan yang ada, atau pengalaman praktis dengan siswa yang mengalami kesulitan belajar, analisis suatu tugas, dan sebagainya. Berbeda dengan tujuan umum pada taksonomi bloom, disini tujuan terminal perlu dinyatakan dalam bentuk yang dapat dilihat dan diukur seperti yang dinyatakan oleh mager.hal ini untuk mempermudah keberhasilan siswa dalam mencapai tujuan instruksional tersebut.

2. Setelah penenetuan tujuan terminal ialah menentukan macam belajar apa yang akan dipelajari siswa berdasarkan klasifikasi Gagne (lima macam belajar). Untuk itu tujuan instraksional dipecah pecah menjadi ketrampilan-ketrapilan yang perlu dipelajari siswa dalam mencapai tujuan instruksional.

3. Identifikasi kemampuan awal siswa dan karakteristik siswa. Disini ialah menentukan ketrampilan ketrampilan apa yang telah dimiliki siswa agar dpt mengikuti program instruksional. serta karakteristik siswa secara umum dan gaya belajar siswa

4. Merumuskan tujuan instruksional khusus, tujuan-tujuan khusus ini harus relevan dengan ketrampilan ketrampilan yang telah di identivikasikan dalam analisis tugas. 
Patokan-patokan yang dipakai untuk mengukur keberhasilan pencapaian tujuan instruksional khusus ini dapat dikonsultasikan pada para ahli.

5. Pengembangan butir-butir tes berdasarkan acuan patokan, yang selanjutnya akan dipakai untuk mengukur sejauh mana siswa telah mencapai tujuan instruksional. Hal ini dapat dilakukan dengan membandingkan penampilan siswa dalam pengujian dengan patokan yang telah ditentukansebelumnya. Disini Dick dan carey menyatakan adanya empat macam tes yaitu:

a. Tes untuk mengukur kemampuan awal yang merupakan prasyarat bagi program instruksional tersebut.

b. Tes awal untuk mengukur sejauh mana siswa telah menguasai materi yang akan diajarkan

c. Tes selama siswa sedang didalam proses belajar untuk melihat apakah siswa dapat menangkap apa yang telah diajarkan

d. Tes akhir untuk mengukur semua tujuan instruksional yang ada.

6. Pengembangan strategi instruksional yang akan memberikan kegiatan-kegiatan dan pengalaman belajar pada siswa. Disini diterapkan prinsip-prinsip belajar serta hasilhasil penelitian di bidang psikologipendidikan serta teknologi instruksional. Langkah ini terdiri dari empat macam langkah kegiatan, yaitu:

1) Aktifitas pre-instruksional yang mencakup cara menarik perhatian dan membangkitkan motivasi siswa, penyampaian tujuan pembelajaran pada peserta didik.

2) Presentasi informasi disini diberikan materi yang diurut berdasarkan analisis hirarki tugas (dari muda ke yang sulit)

3) Partisipasi siswa yang merupakan bagian terpenting dalam proses belajar disini perlu dipilih aktivitas-aktivitas untuk siswa yang relevan dengan tujuan instruksional yang harus dicapai siswa disini perlu dilakukan penguatan guna untuk keberhasilan dalam proses belajar.

4) Pengujian dilakukan aktifitas untuk menguji keberhasilan siswa selama mengikuti kegiatan belajar mengajar.

5) Aktivitas lanjutan ini menyangkut pertanyaan pertanyaan apakah ada perlu remedial, langkah ini dilakuakan apabila ada umpan balik dari hasil uji coba dilapangan.

7. Perencanaan instruksional ini adalah pengembangan dan pemilihan bahan atau materi instruksional terdapat tiga kemungkinan:

a) Bahan dapat dipelajari secara individual tanpa bantuan guru

b) Bahan diberikan guru seluruhnya, sesuai dengan strategi yang telahdikembangkan

c) Guru memakai bermacam macam sumber, yang dapat dipelajari secara individual maupun tanpa bantuan guru.

8. Mengadakan evaluasi vormative yang dapat dipakai untuk umpan balik sistem yang 
dirancang sehingga dapat berfungsi secara lebih efetif dan efisien

9. Revisi sistem yang dilakukan berdasarkan umpan balik yang dilakkan berdasarkan umpan balik yang diperoleh selama evaluasi formatif disini terdapat dua macam revisi yaitu:

a. Perubahan dalam isi dalam substansi sehingga dapat lebih efektif

b. Perubahan prosedur

10. Evaluasi sistem sumatif yang dilakukan untuk mengukur tingkat keberhasilan siswa dalam mencapai tujuan instruksional terminal. Disamping itu evaluasi sumatif dipakai juga untuk mengukur keefektifan system instruksional yang dirancang sendiri.

Kekuatan model ini terletak pada analisis tugas secara terperinci serta penysunan tugas tugas tersebut serta tujuan instruksional khusus secara hirarkis. Dengan demikian telah diketahui dengan pasti langkah -langkah yang harus dilakukan oleh sisiwa untuk mencapai tujuan terminal system. Disamping itu ada ujian berulangkali menyebabkan hasil yang akan diperoleh system dapat diandalkan. Karena ujian ini dilakukan berulang kali inilah maka modeltersebut digolongkan kepada model yang berorientasi pada hasil.

Hanry Lehman, bahwa analisis pembelajaran mencakup delapan tahapan kegiatan sebagai berikut:

1. Melakukan analisis kebutuhan pembelajaran (needs analysis)

2. Menetapkan tujuan pembelajaran

3. Menganalisis hambatan, tantangan, kekuatan, dan kelemahan pembelajaran

4. Merancang disain pembelajaran berdasarkan tujuan yang ditetapkan

5. Implementasi pembelajaran

6. Mengevaluasi kegiatan penerapoan pembelajaran

7. Merevisi disain pembelajaran berdasarkan hasil evaluasi, dan

8. Memodifikasi disain pembelajaran.

Sesuai dengan tuntutan dan kebutuhan kontekstual pengembangan pembelajaran Hanry Lehman di atas dapat dimodifikasi sebagai berikut:

1. Analisis kebutuhan pembelajaran, terdiri dari kegiatan:

a. Analisis prilaku dan karakteristik siswa,

b. Menganalisis hambatan, tantangan, dan peluang pembelajaran

2. Merancang desain pembelajaran, teidiri dari kegiatan;

a. Menetapkan tujuan pembelajaran

b. Memilih dan mengembangkan bahan ajar

c. Memilih dan merancang strategi, metode pembelajaran

d. Memilih dan mengembangkan sistem evaluasi

3. Implementasi pembelajaran sambil dievaluasi

4. Refleksi dan modifikasi desain, sesuai hasil evaluasi pembelajaran. 


\section{PEMILIHAN BAHAN AJAR}

Memilih dan mengembangkan bahan ajar, sangat bergantung pada tujuan pembnelajaran. Pengembangan bahan ajar berkaitan dengan dua aspek mendasar yakni skup dan sequence bahan ajar (keluasan/ ruang-lingkup bahan ajar dan tahapan-tahapan hierarkhis bahan ajar). Skop atau ruang-lingkup bahan ajar berkaitan dengan keluasan bahan ajar yang dipandang relevan untuk mengantarkan peserta didik mencapai tujuan, dan sequence abahan ajar menyangkut tahapan-tahapan struktural bahan ajar dengan pertimbangan kapan bahan ajar perlu didahulukan atau diakhirkan untuk dipelajari siswa.

Pengembangan sequence bahan ajar terdapat beberapa model yakni;

1. Sequence logis; yakni pengembangan bahan ajar dimulai dari yang mudah menuju yang kompleks, dari bagian-bagian menuju keseluruhan

2. Sequence psikologis yakni; pengembangan bahan ajar kebalikan dari nomor 1 di atas.

3. Sequence historis; pengembangan bahan ajar sesuai dengan fenomena-fenomena kesejarahan, yuang bergerak maju dari fenomena awal meunju berikutnya.

4. Sequence kronologis; pengembangan bahan ajar sesuai dengan krponologis kejadiannya secara berurutan, hamper sama dengan sequence historis tapi bukan kesejarahan.

5. Sequence kausal; yakni pengembangan bahan ajar didasarkan pada kasus- atau fenomena tertentu yang dipandang sebagai penyebab perlu dipelajari lebih dahulu sebelum sesuatu yang dianggap sebagai akibat.

6. Sequence spiral; yakni pengembangan pembelajaran sesuai dengan sesuatu atau fakta tertentu yang sangat berdekatan dengan siswa, kemudian dikembangkan menuju kepada yang lebih luas dan lebih tinggi.

Ada beberapa prinsip yang perlu diperhatikan dalam pemilihan bahan ajar atau materi pembelajaran, yaitu:

1. Prinsip relevansi artinya keterkaitan. Materi pembelajaran hendaknya relevan atau ada kaitan atau ada hubungannya dengan pencapaian standar kompetensi dan kompetensi dasar.

2. Prinsip konsistensi artinya keajegan. Jika kompetensi dasar yang harus dikuasai siswa empat macam, maka bahan ajar yang harus diajarkan juga harus meliputi empat macam.

3. Prinsip Kecukupan artinya materi yang diajarkan hendaknya cukup memadai dalam membantu siswa menguasai kompetensi dasar yang diajarkan. Materi tidak boleh terlalu sedikit, dan tidak boleh terlalu banyak.

\section{PENUTUP}

1. Secara umum strategi dapat diartikan sebagai suatu garis-garis besar haluan untuk bertindak dalam usaha mencapai sasaran yang telah ditentukan. Dihubungkan 
dengan belajar mengajar, strategi juga bisa diartikn sebagai pola-pola umum kegiatan guru dan anak didik dalam perwujudan kegiatan belajar mengajar untuk mencapai tujuan yang telah digariskan.

2. Berdasarkan pada pengertian pembelajaran, maka diperlukan sekurang-kurangnya lima kriteria yang harus dipenuhi dalam model pembelajaran atau pengembangan pembelajaran yaitu: 1) mempunyai tujuan; 2) keserasian dengan tujuan; 3) sistematik; 4) mempunyai kegiatan evaluasi; dan 5) menyenangkan

3. Memilih dan mengembangkan bahan ajar, sangat bergantung pada tujuan pembnelajaran. Pengembangan bahan ajar berkaitan dengan dua aspek mendasar yakni skup dan sequence bahan ajar (keluasan/ ruang-lingkup bahan ajar dan tahapan-tahapan hierarkhis bahan ajar). Skop atau ruang-lingkup bahan ajar berkaitan dengan keluasan bahan ajar yang dipandang relevan untuk mengantarkan peserta didik mencapai tujuan, dan sequence abahan ajar menyangkut tahapantahapan struktural bahan ajar dengan pertimbangan kapan bahan ajar perlu didahulukan atau diakhirkan untuk dipelajari siswa.

\section{DAFTAR PUSTAKA}

Baharuddin, pendidikan \& psikologi perkembangan, Jogjakarta: ar-ruzz media, 2010.

Denim, Sudarwan, Khairil, psikologi pendidikan, bandung: alfabeta, 2011.

Hamalik, Oemar, psikologi belajar \& mengajar, bandung: sinar baru algensindo, 2012.

Mahmud, psikologi pendidikan, bandung: pustaka setia, 2009.

http://biologi-lestari.blogspot.com/2013/03/teori-teori-belajar-dan-pembelajaran.html, diakses tanggal 19 november 2016.

http://gioakram13.blogspot.com/2013/05/teori-belajar-menurut-para-ahli_29.html, diakses tanggal 12 desember 2016.

http://kosrah.blogspot.com/2013/06/macam-macam-teori-belajar-berdasarkan.html. diakses tanggal 10 desember 2016.

http://lathifatuss.blogspot.com/2013/06/teori-belajar.html, diakses tanggal 19 november 2016.

http://tutorialpendidikankewarganegaraan.blogspot.com/2011/09/tutorial-pendidikanppkn.html, diakses tanggal 19 november 2016. 